\section{Åpne kontorlandskap stresser hjernen}

Hodepine, stress og mindre overskudd til familien. Det er hverdagen for dem som jobber i åpent kontorlandskap.

Det viser en undersøkelse Analyse Danmark har gjort for Ugebrevet A4 (1). $60 \%$ av de spurte opplever nedsatt konsentrasjon, $35 \%$ sier de gjør feil i jobben, og for nesten en firedel er støyen så sjenerende at de må jobbe overtid for å få ro til å få gjort sine oppgaver.

\section{Ikke nødvendigvis effektivt}

Mange bedrifter legger om fra cellekontorer til helt eller delvis åpne kontorlandskap, blant annet på grunn av dyr husleie. Konsulent Stig Rusti i Fourstep mener imidlertid at man risikerer en kostbar produktivitetsdreper.

- Våre funn tyder på at man risikerer opp mot $30 \%$ mindre effektivitet. Man kan kanskje halvere husleien og øke bunnlinjen, men vinningen går raskt opp i spinningen, sier han til E24 (2).

\section{Støy stresser hjernen}

Overlege og hjerneforsker Troels W. Kjær ved Klinisk Neurofysiologisk Klinik ved Rigshospitalet i København forklarer hvorfor støy $\mathrm{i}$ åpne kontorlandskap kan føre til hodepine og stress.

- Hjernen har til oppgave å finne en mening i det vi til enhver tid hører. Når det ikke er et mønster i lyden, kaller vi det støy. Her kjemper hjernen med å finne et mønster i noen lydinntrykk som ikke er relevante eller gir en dypere mening. Og når hjernen ikke klarer dette, blir den stresset, sier han til Ugebrevet A4 (3).

Kjær mener det over tid ikke er bra for kroppen å sitte i slik støy. - Det å sitte i åpent kontorlandskap, hvor hjernen hele tiden prøver å finne mønster i støyen, gjør at man får altfor stor påvirkning av stresshormoner. Det er det som kjennetegner folk med posttraumatisk stress og kronisk tretthetssyndrom, sier Kjær.

\section{Fleksible kontorer er best}

Christina Bodin Danielsson, arkitekt og kontorforsker ved Stressforskningsinstitutet ved Stockholms universitet, har skrevet doktoravhandling om kontordesign, helse og jobbtilfredshet (4). Danielsson sier til bladet Personal och Ledarskap at før man innfører åpent kontorlandskap, bør medarbeiderne intervjues om sine virkelige behov ut fra sine arbeidsoppgaver. Avhandlingen hennes viser at fleksible kontorer er best for helse og velvære. Som nummer to kommer cellekontorer, mens tradisjonelle kontorlandskap med 10-24 personer kommer dårligst ut.

\section{Eline Feiring \\ Tidsskriftet}

\section{Litteratur}

1. Storrum stordumper - vi har intet lært. Ugebrevet A4. www.ugebreveta4.dk/ storrum-stordumper-vi-har-intet-laert_13927.aspx (11.4.2014).

2. Forsker slakter åpne landskap. E24. http://e24.no/jobb/forsker-slakter-aapnekontorlandskap/22677795 (11.4.2014).

3. Støy på kontoret gir hodepine og stress. Ugebrevet A4. www.ugebreveta4.dk/ stoej-paa-kontoret-giver-hovedpine-og-stress_19395.aspx (11.4.2014).

4. The office - an explorative study: architectural design's impact on health, job satisfaction \& well-being. Doktoravhandling. http://kth.diva-portal.org/smash/ record.jsf?pid=diva2: 349771 (11.4.2014)

\section{Are Helseth ny sjef i LHL}



Are Helseth (f. 1955) tiltrer 1.8. 2014 en nyopprettet stilling som medisinsk sjef i Landsforeningen for hjerte- og lungesyke (LHL) og som styreleder i LHL Holding AS.

Helseth har siden 2009 vært første vararepresentant til Stortinget fra Akershus og var fast møtende vararepresentant mens Anniken Huitfeldt var statsråd.

Tidligere har han blant annet vært administrerende direktør ved Fürst Medisinsk Laboratorium, prosjektdirektør i Helse- og omsorgsdepartementet og administrerende direktør ved Akershus universitetssykehus.

Han tok medisinsk embetseksamen i Oslo i 1981, tok doktorgraden i 1989 og ble godkjent spesialist i patologi i 1990 og i generell kirurgi i 1997.

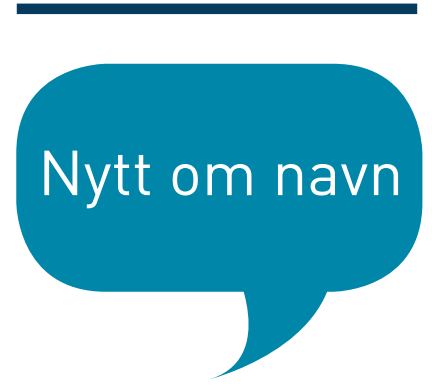

Jens Petter Rønning fullførte sine medisinstudier i Polen våren 2013. Han trives nå i sitt arbeid som turnuslege ved kirurgisk avdeling på Sørlandet sykehus, Kristiansand. I september går han videre til medisinsk avdeling, der han blir i seks måneder.

Halfdan Kierulf er nevrolog og fylte nylig 70 år. I mars stilte han ut sine malerier under «Nevrodagene», som er Norsk nevrologisk forenings årlige fagdager. Han ble også valgt til æresmedlem i foreningen.

Ole Kristian Losby er turnuslege og medarbeider i Tidsskrift for Den norske legeforening. I april utfordret han helseministeren på om legers ytringsfrihet er godt nok ivaretatt, i Søndagsavisa, NRK P2 (http://radio.nrk.no/serie/soendagsavisa\#t=5m57s).

Paul Jostein Lereim er blitt tildelt Kongens Fortjenstmedalje. Lereim er professor i ortopedi og regnes som en pioner innen hofte- og kneprotesekirurgi i Norge. (www.kongehuset.no) 